\title{
Strategies for Community and Industry Water Management in the Oil Producing Region of North Dakota
}

\author{
Robert R. Hearne ${ }^{1, *}$ and Felix Fernando ${ }^{2}$ \\ 1 Department of Agribusiness and Applied Economics, North Dakota State University, Fargo, ND 58108, USA \\ 2 Hanley Sustainability Institute, University of Dayton, Dayton, OH 45469, USA; wfernando1@udayton.edu \\ * Correspondence: robert.hearne@ndsu.edu; Tel.: +1-701-231-6494
}

Academic Editor: Athanasios Loukas

Received: 28 June 2016; Accepted: 1 August 2016; Published: 5 August 2016

\begin{abstract}
North Dakota's Bakken region has surged to become an important oil-producing region. One of the key concerns for ensuring sustained growth in this region is the availability of water. This paper will review current water management practices and review alternative policies with special attention to the needs of North Dakota's rural communities. Although the region is semi-arid, there is an abundance of water available in the Missouri River and Lake Sakakawea. Efforts to utilize available water have been impaired by the US Army Corps of Engineers' reservoir management polices as well as difficulties in constructing infrastructure during boom drilling. North Dakota was fortunate to dedicate oil revenue for water development. In addition, the expansion of regional water systems has been partially funded by sales to drilling operations. These water systems will benefit both industry and local communities.
\end{abstract}

Keywords: water resources management; fracking; Missouri River; Bakken Oil Shale Region; community water supply

\section{Introduction}

A standard approach to addressing water management stresses, especially in the western United States, is to reiterate that water is scarce, with competing uses, and that society is better off when water flows to its highest valued use. The substantial increase in water demand because of the increased oil drilling activity associated with North Dakota's oil industry and the growing communities in western North Dakota has challenged the region, and brought about conflict between the state and federal water management agencies. However, because of the Missouri River and the US Army Corps of Engineers' (USACE) managed reservoirs, the expectation of water scarcity is somewhat inappropriate. This paper will review current water management practices and review alternative policies with special attention to the needs of North Dakota's rural communities.

North Dakota's shale oil producing Bakken region has rapidly surged to become the nation's second most productive oil-producing region. It has experienced a large increase in population along with expanded demand for private and public services. One of the key concerns for ensuring sustained growth in this region is the availability of water. Shale oil drilling in the Bakken consumes a considerable amount of water. Recent estimates report nearly 3.6 million gallons per well for fracking and drilling [1]. However, population increases in the Bakken imply that municipal and rural water demands will also increase intensifying the competition for this scarce and valuable resource.

Water is a scarce and valuable economic good. In western North Dakota, the services provided by surface and groundwater resources include: (1) water supply for human consumption; (2) irrigation; (3) water supply for livestock; (4) water supply for fracking and drilling activities; (5) other industrial 
water uses including evaporative cooling; (6) hydropower production; (7) recreation; and (8) instream ecosystem maintenance. The rapid shift in demand for water that accompanied the oil boom has stressed water delivery services and resulted in a number of emergency measures, such as temporary sales of irrigation water to the oil industry and temporary permits to tap scarce groundwater sources. However, the State of North Dakota has long maintained that the water source best suited to meet the needs of western North Dakota is the Missouri River. Competition for water among water uses in North Dakota also involves competition for Missouri River water use in other parts of the basin.

Efforts to provide "surplus water" from the USACE managed Lake Sakakawea have been mired in a political dispute between the state of North Dakota and the Army Corps over the definition of "surplus" water and the precedent of paying for Missouri River water. The North Dakota State Water Commission (SWC) has approved a number of temporary solutions, such as temporary transfers of irrigation water to private sector water depots. These temporary measures have alleviated water shortages and maintained drilling operations, but do not provide the security needed for sustained growth. Therefore, this paper's focus on current water management strategies and alternative policies will assist and inform policy makers and water management practitioners in western North Dakota in developing adept strategies and plans to address increased industrial and community water demands. This information will also help other pertinent policy makers and water practitioners in areas experiencing fracking as increased demand for water is a central issue associated with the process of hydraulic fracturing.

The information presented in the subsequent sections are based on public information, published literature, as well as open-ended question-based interviews with pertinent state, city, and employees of the three regional water supply programs in western North Dakota. Participants were recruited using a purposive sampling approach [2], where all the participants held managerial level positions in the respective state, city, and water programs. The next section of this paper presents the water-related challenges faced in the region and is followed by a section on the efforts made to face these challenges. The paper's conclusions focus on strategies for regional development.

\section{Water Management in Western North Dakota}

Western North Dakota is mostly semi-arid with average annual precipitation averaging between 330 and $500 \mathrm{~mm}$, with approximately 75 percent of precipitation between April and September. Precipitation can be highly variable with periods of drought and flood. North Dakota has been in a wet cycle since 1993 with frequent flooding, especially in the Red River and Devils Lake Basins [1,3].

Land use is traditionally dedicated to crop production and pasture. There is very limited irrigation, most of which is from groundwater sources. Agriculture is the preeminent industry in North Dakota, and this has not changed with the development of the oil industry in the 21st century. Most crops are rain fed and there are significant livestock operations. Eighty-four percent of agricultural income in the sixteen county areas comes from crop production [4].

North Dakota's shale oil-producing region is defined by the subsurface Bakken and Three Forks shale oil deposits. The Bakken boom coincides with the recent innovations of horizontal drilling and hydraulic fracturing, better known as fracking. The four county core area of oil production consists of McKenzie, Mountrail, Dunn, and Williams counties, generally accounting for 80 percent of state production (see Figure 1). However, there remains some production outside of the Bakken formation, including the oil produced in Bowman County (see Table 1). 


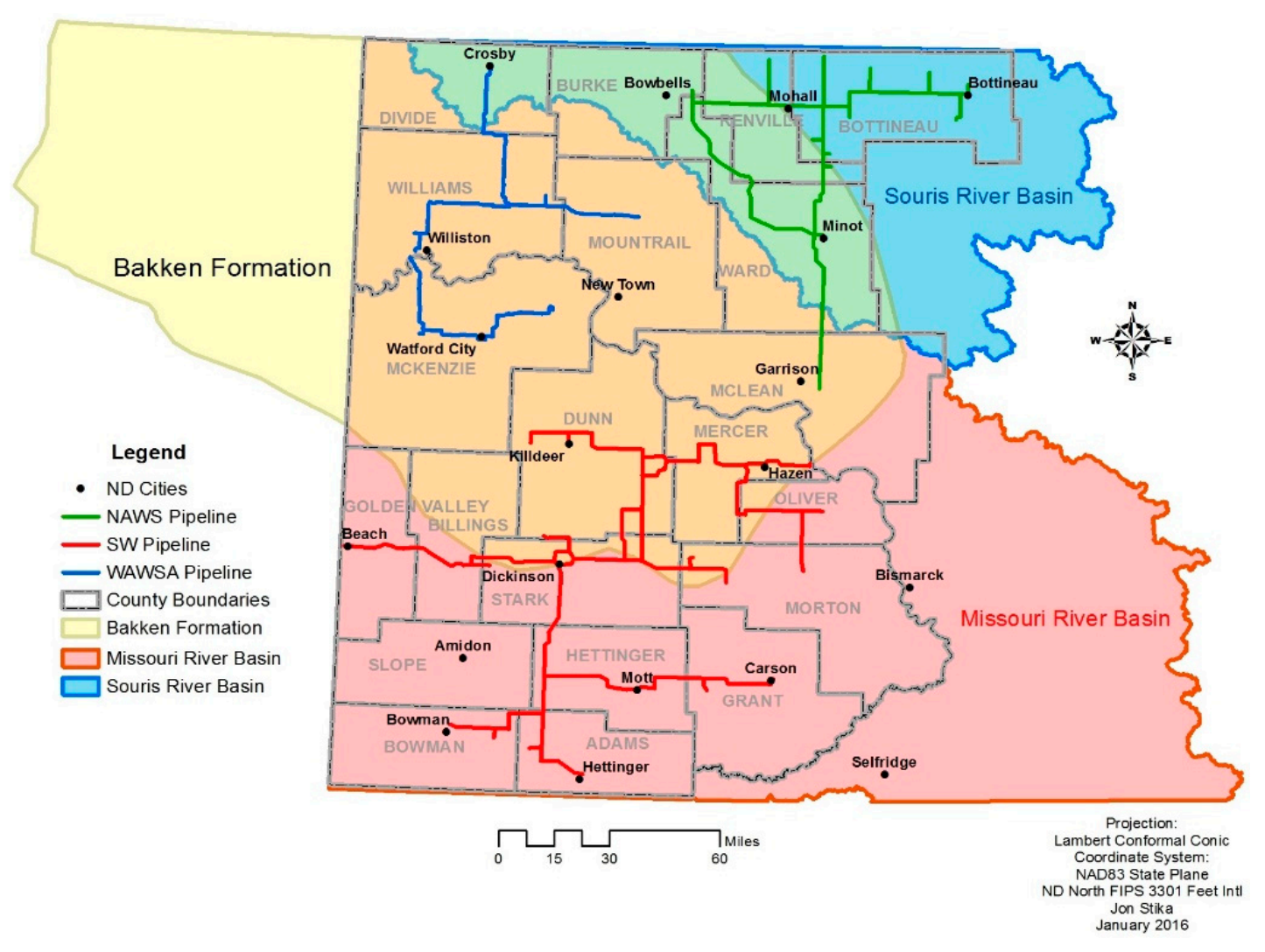

Figure 1. Map of western North Dakota with water systems.

Table 1. Top ten 2014 oil producing North Dakota counties.

\begin{tabular}{ccccccc}
\hline County & $\begin{array}{c}\text { July 2015 } \\
\text { Population }\end{array}$ & $\begin{array}{c}\text { Population } \\
\text { Change } \% \\
\mathbf{4 / 2 0 1 0 - 7 / 2 0 1 5}\end{array}$ & $\begin{array}{c}\text { Projected } \\
\mathbf{2 0 2 5} \\
\text { Population }\end{array}$ & $\begin{array}{c}\text { Hectares of } \\
\text { Farmland } \\
\mathbf{2 0 1 2}\end{array}$ & $\begin{array}{c}\text { Irrigated } \\
\text { Hectares } \\
\mathbf{2 0 1 2}\end{array}$ & $\begin{array}{c}\text { Kiloliters of } \\
\text { Oil Produced } \\
\mathbf{2 0 1 4}\end{array}$ \\
\hline Williams & 35,294 & 57.6 & 51,106 & 430,225 & 2255 & $8,908,714$ \\
Stark & 32,154 & 32.9 & 42,191 & 335,706 & 327 & $1,165,593$ \\
Mountrail & 10,331 & 34.6 & 13,575 & 389,984 & 83 & $15,186,596$ \\
McKenzie & 12,826 & 101.7 & 17,110 & 430,663 & 8059 & $21,110,355$ \\
Bottineau & 6716 & 4.5 & 10,721 & 363,987 & $\mathrm{D}^{*}$ & 422,597 \\
Dunn & 4646 & 31.4 & 5433 & 417,376 & 153 & $10,187,811$ \\
Bowman & 3294 & 4.5 & 3804 & 295,553 & 588 & $1,293,336$ \\
Divide & 2450 & 18.3 & 4948 & 228,637 & 958 & $2,375,583$ \\
Burke & 2308 & 17.3 & 2989 & 240,826 & $\mathrm{D}$ & $1,035,997$ \\
Billings & 936 & 19.5 & 1315 & 292,294 & 0 & 860,692 \\
\hline 10 Counties & 110,019 & 45.7 & 151,877 & $3,425,251$ & 12,423 & $61,686,582$ \\
\hline North Dakota & 756,927 & 12.5 & 841,820 & $15,889,016$ & 88,386 & $63,099,270$ \\
\hline
\end{tabular}

Notes: Sources: [4-7]; * “D” implies that information is withheld to protect information on individual farms.

During the mid-2000s, well-drilling activities increased as crude oil prices increased. Drilling activity surged after 2009, when numerous drilling rigs entered the state. Recent estimates suggest that oil drilling will continue to increase through 2035, when an estimated 30,000-46,000 wells will be completed [8]. However, these estimates preceded low oil prices in 2015, which brought a slowdown of new drilling. From July 2014 to July 2015, the number of drilling rigs in North Dakota fell from 192 to 70. However, the number of producing wells in North Dakota continues to rise (see Figure 2), and the state's oil production peaked in December 2014 at 38.1 million barrels and declined slightly to average 33.2 million barrels during the first four months of 2016 (North Dakota Department of Mineral Resources). 


\section{North Dakota Production Wells, Production and}

Price

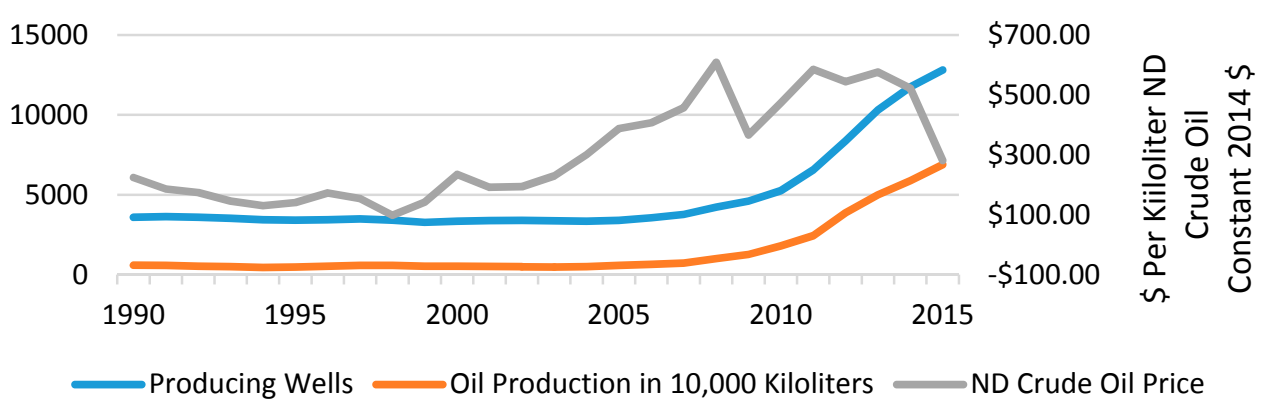

Figure 2. North Dakota Petroleum Production and Prices, 1990-2015 (Source: [7,9]).

The drop in oil prices in the first half of 2015 has definitely slowed down, but not stopped, the pace of shale oil drilling in western North Dakota. Breakeven prices for the four county core production areas are US $\$ 30-U S \$ 41$ per barrel [10]. Prices did dip below US\$30 in early 2016, and production slowed only moderately as most producers maintained production. Based upon 2013 projections of future drilling, more than 67 percent of the projected producing wells-under current technology and recovery rates-still remain to be completed $[7,8]$. With the decline in oil prices, it can be anticipated that this activity would be spread over a longer period than initially projected.

Most pertinent to this paper on western North Dakota water management is the use of water in oil drilling, fracking, and well maintenance. The agency responsible for manage water allocation in North Dakota is the SWC. The SWC follows provisions of the North Dakota Century Code, which are based upon prior appropriation. The SWC reports that average water use to frack a well is 11 acre feet or 13,570 cubic meters. Additionally, each well requires 1150 cubic meters of water as drilling fluid. The use of water for oil field operations is a function of drilling and oil production and the industry demand for water will abate as low global oil prices decrease drilling. However, although drilling may substantially decrease, production from existing wells will continue, and, over the course of the productive life of a well, another 13,570 cubic meters will be used on average.

The State Water Commission stresses that less than 5 percent of the state's consumptive water use is used in fracking. However, fracking flowback water in North Dakota is withdrawn from the hydrologic cycle. Wastewater from the fracking process is extremely saline and is much more difficult to recycle than fracking flowback from the Marcellus Shale formation in the eastern USA. Only a very small percentage of Bakken fracking wastewater has been recycled. Incentives exist to develop improved recycling technologies, but, currently, fracking flowback water is trucked to deep saltwater wells. The oil industry and the state vehemently deny that fracking and wastewater disposal can have a negative impact upon the much shallower groundwater aquifers. However, over 3900 wastewater spills have been recorded, with persistent inorganic contamination [1,11,12].

Most of the water used in the drilling, fracking, and production process is supplied to the well sites through private water sellers. Often, these sellers are using temporary water permits granted by the SWC. North Dakota's water law specifies priority of use for water rights. These are: (1) domestic; (2) municipal; (3) livestock; (4) irrigation; (5) industrial; and (6) recreation, fish, and wildlife. Market sales of water use rights from a higher to a lower priority use are prohibited. However, the SWC has issued a number of permits for temporary sales of irrigation water to industrial users. These temporary permits allowed irrigators to sell volumes of water to the oil industry, without a water law reform that would facilitate wider water markets.

There are limited groundwater aquifers in western North Dakota. These aquifers play a crucial role in supplying water to rural households and livestock operations. These include bedrock aquifers with high levels of salinity. The Fox Hills aquifer is an important resource in western North Dakota but 
has been declining from ranch and household appropriation. The SWC is trying to abate this decline by limiting new permits for this resource. Limited groundwater capacity has led the state of North Dakota to maintain a policy to restrict further allocation of groundwater in certain areas $[1,13]$.

Many small communities, as well as farms and ranches that are not serviced by a rural water supply project, rely on groundwater for domestic water use. Water quality is often poor, necessitating families to purchase and transport bottled water. Household appliances are often corroded by hard water.

A large majority of the oil production in this region is within the Missouri River watershed. However, some drilling and production occurs in the Mouse River basin (known as the Souris River in Canada). The SWC has consistently maintained that the water resource appropriate for use in the Bakken is the Missouri River and Lake Sakakawea. Lake Sakakawea is one of the six mainstream reservoirs constructed under the Pick-Sloan program and operated by the US Army Corps of Engineers (USACE). Through its operation of the integrated dam and reservoir system, the USACE has become the de facto river master of the Missouri River. The Pick Sloan dams were built to provide multiple services: flood control, navigation, irrigation, municipal and industrial water use, hydroelectric generation, and recreation. The particular priorities given to these designated uses along with the maintenance of the river's ecosystem has been subject to numerous court cases and ongoing disputes [14,15].

The original Pick-Sloan plan for the development of the Missouri River basin included a Bureau of Reclamation irrigation project in North Dakota, and included authorization for an inter-basin transfer. However, North Dakota soils were determined to be unsuitable for surface irrigation. Later, North Dakota pushed for construction of the Garrison Diversion to bring Missouri River water to eastern North Dakota and ensure secure potable water supplies for the state's population centers. This diversion is a priority for North Dakota, but it is strongly opposed by Canada, which is afraid of the transfer of harmful biota from the Missouri River basin to the Hudson Bay basin, and by Missouri, which is opposed to any diversion that would reduce flows that enable navigation in the lower stretches of the river [16].

Thus, due to low population density, soils that are not suitable for surface irrigation system in western North Dakota, and difficulties in diverting water to the Red River basin, North Dakota has used very little Missouri River water. Annual flows in Williston, North Dakota, before the entrance to Lake Sakakawea has varied between 11 and 32 cubic kilometers annually (from 1898 until 1960) with a mean annual flow of 21.7 cubic kilometers [1,17]. Of this, only 0.70 cubic kilometers are permitted for use in North Dakota. In addition, 80 percent of these permitted withdrawals are for non-consumptive power generation and cooling and returned to the river.

A recent pertinent dispute involves the use of water stored in Lake Sakakawea for fracking and oil production. As demand for water surged in the Bakken Region, the USACE released a Final Surplus Water Report and Environmental Assessment in March 2011. The Environmental Assessment proposed a temporary sale of Lake Sakakawea water to supply North Dakota's oil industry during its initial fracking and drilling period [18]. Although the USACE does not claim the right to allocate water, it does control the reservoirs and can restrict water withdrawals for state allocated water because it controls the land immediately riparian to the reservoirs.

The 1944 Flood Control Act, which authorized the Pick-Sloan program, allows the USACE to sell 'surplus' water to domestic and industrial users. This is one of the few cost recovery mechanisms available to the federal government. The USACE controls the water in Lake Sakakawea and maintains a riparian right of way around the lake. Thus, any water permits granted to users by the NDSWC under the prior appropriation based state law cannot be withdrawn from the lake. A similar USACE policy should be expected for the Lake Oahe, which is the reservoir for the South Dakota's Oahe Dam but extends north into North Dakota. Thus, the USACE restricts access to nearly 70 percent of North Dakota's portion of the Missouri River. This USACE policy does not restrict North Dakota from appropriating Missouri River water, but it does restrict users from extracting water from the lakes. This imposes extra transportation costs on North Dakota water users. 
The USACE analysis suggested that the financial cost of this water supply, in terms of the updated cost of constructing the Garrison Dam, was substantially cheaper than the alternative, which is water withdrawn from the Missouri River, treated at the Williston Water Treatment plant, and transported to communities through existing and constructed pipelines.

The state of North Dakota objected to the USACE proposal and argued that the State is entitled to allocate prior appropriation rights to the natural flow of the Missouri River, and the significant sacrifices made by the state and riparian tribes in terms of losses of land have never been compensated. The USACE proposal is considered by North Dakota as a 'taking' of its rightful water [17].

Much of this debate revolves around the definition of 'surplus water.' Clearly, the USACE defines 'surplus water' as any water in the reservoir that is not needed to fulfill its federally mandated purposes. This would include water that North Dakota perceives it has the right to appropriate without payment. An alternative definition would limit 'surplus water' to the stored flood waters that would be surplus to the natural flow of the river. This discrepancy was noted in the congressional debate on the 1944 Flood Control Act when members of Congress supported the North Dakota position [14].

In any case, the state's initial protests led to a July 2012 addendum to the March 2011 Draft Environmental Assessment stating that charges for water withdrawals would not be applied until the USACE completed a review of national policy on surplus water use. Before that review was released, Congress passed the 2014 Water Resources Development Act, which established a general policy of not charging a fee for a surplus water agreement [19].

Both the USACE and the SWC agree that there is an immediate need for water to support drilling and fracking operation for the next few years. Both agencies plan for water use in oil drilling and production over a ten-year period (with similar estimates of drilling operations that preceded the 2015 drop in oil prices and corresponding drilling slowdown). The estimates for permanent water needs vary differently between these agencies. Both agencies use population projections supplied by the North Dakota Data Center (renamed Center for Social Research) at North Dakota State University. The USACE used a pre-boom 2002 estimate for 2020 population in a six county area, which predicted a 14 percent decrease in population. The SWC uses a 2012 population prediction from the same institute, which predicts an 84 percent increase in population in the same counties by 2020 . These more recent population estimates for the Bakken region suggest that the immediate boom that has coincided with rapid drilling operations will evolve toward a long-term increase in population needed to service the region's oil production.

\section{Regional Water Systems}

The SWC has addressed both the temporary and permanent need for further water in the Bakken region by supporting the expansion of three regional water supply programs established to bring Missouri River water to municipal and rural water supply systems. These expansion projects are designed to improve the security of water delivery in periods of scarcity and to improve the quality of water delivered in municipal and rural systems. By improving water delivery to small communities and rural homesteads, these water systems increase the supply of quality housing available to serve the growing population. Rural water systems not only serve households but also bring high quality water to livestock operations. These existing regional water supply programs include: (i) the Western Area Water Supply Project; (ii) the Northwest Area Water Supply Project; and (iii) the Southwest Pipeline Project.

Both the Southwest Pipeline and the Northwest Area Water Supply (NAWS) projects are part of the Municipal, Rural and Industrial (MR\&I) Water Supply Program, created by the Garrison Diversion Act of 1986, to bring Missouri River water to North Dakota communities, with an initial appropriation of US\$200 million. Because these projects are federally supported, they do have right-of-ways to access Lake Sakakawea water. An additional US\$600 million was authorized under the 2000 Dakota Water Resources Act, which included funding for tribal water systems and was to be implemented by the Bureau of Reclamation. These funds require annual congressional approval, and, as of late 
2014, US $\$ 355$ million has been approved. After a spike in federal funding in 2009, supplemented by economic stimulus spending, federal expenditures have decreased. Funding has been supplemented by local taxes and state appropriations. Other federal funds available for water supply include the Drinking Water State Revolving Loan Fund, which is a United States Environmental Protection Agency program administered by the North Dakota Department of Health. This program provides low interest loans for capital investments intended to improve drinking water quality and increase compliance with the Safe Water Drinking Act [1].

Water systems on the Spirit Lake, Fort Berthold, Turtle Mountain and Standing Rock Indian Reservations also received US\$200 million in funding under the 2000 Dakota Water Resources Act. State funding was also authorized. The Bureau of Reclamation uses these funds to support capital construction costs and maintenance of tribal water systems, although the tribes manage the systems.

State support for regional water systems has substantially increased with the expansion of the Resources Trust fund, which receives 20 percent of the state's oil extraction tax. The funds also receive income from loan repayments. The Resources Trust Fund had a total balance of US\$562 million on 1 April 2015 (North Dakota State Treasurer, undated). In addition, the Water Development Trust Fund was created in 1999 and is funded by part of the funds received in the 1998 tobacco settlement. The SWC also has bonding authority, but all bonds greater than US $\$ 2$ million need to be authorized by the Legislature.

The Southwest Pipeline Project (SWPP) is owned by the state and managed by the Southwest Water Authority (SWWA), a political subdivision created by the state. Board members are elected to represent each of the systems twelve counties as well as two from the city of Dickinson and one from the city of Mandan. As of 2013, the Southwest Water Authority serves more than 56,000 residents in 31 communities (see Figure 1). The Southwest Water Authority has been quite active in extending service to smaller communities and to meet new population growth. The Oliver, Mercer, North Dunn (OMND) water treatment plant was completed in 2012 and an expansion of the Dickinson Water Treatment Plant is planned. A new intake from Lake Sakakawea and pump station is being constructed. Funding for the project comes from the sale of water to rural water systems, United States Department of Agriculture Rural Development grants and loans, revenue bonds, as well as the previously mentioned federal and state funding sources. Service area and pipeline extensions have been ongoing, although construction has been limited during years of limited funding. Many farmsteads and communities have signed up for water for Missouri River more than twenty years and are still waiting. The SWWA does engage in industrial water sales to oil drilling and fracking operations. This is not a major source of revenue and according to a Board member, which has been used to supplement the purchase of satellite water monitoring technology. In addition, the City of Dickinson, which receives water from the SWPP, has a depot for industrial water sales.

The NAWS project area is a ten-county region of northwestern North Dakota north of Lake Sakakawea and the Missouri River. This area includes portions of the Mouse (Souris) River basin, which is part of the Hudson Bay drainage area, and thus entails an inter-basin transfer of water. Some communities in Burke and Divide counties chose not to participate in the NAWS project and were not included in the project development. Construction began in 2002 after the Secretary of the Interior found that the project was in accordance with the 1909 Boundary Waters Treaty and an Environmental Assessment found no significant impact. Subsequently, the project has faced a number of legal challenges from the Province of Manitoba, concerned about biota transfer, and from the State of Missouri, protecting downstream navigation. A Final Environmental Impact Statement on Water Treatment was produced in 2008, and a record of decision was signed in 2009. In response to a suit by Manitoba and Missouri, a US District Court ordered further analysis. A Record of Decision of the Final Supplemental Environmental Impact Statement (SEIS) was released in August of 2015. The preferred alternative from the 2015 SEIS was the use of both Missouri River and groundwater for the NAWS water supply with conventional water treatment inside of the Missouri river basin to protect against biota transfer to the Mouse (Souris) River basin. The project construction has continued 
throughout these challenges but the infrastructure will not be used to transfer Missouri River water to the populated communities in the Mouse (Souris) River basin, until the construction of the new water treatment plant. Thus, the communities in the service area have been using less reliable Mouse River water and limited groundwater sources during this decade-long period of court-mandated delay and analysis.

Much of the ten-county NAWS project area will not be serviced by the currently formulated NAWS pipelines. This includes three important oil-producing counties: Williams, Divide, and Mountrail. The Western Area Water Supply (WAWS) project is currently expanding to serve much of these counties as well as much of Burke County, in the NAWS project area and McKenzie County, located south of the Missouri River. The WAWS project is a joint effort by the Williams Rural Water District, the McKenzie County Water District, the City of Williston, the Burke, Divide and Williams Water System Association and the Ray \& Tioga Water Supply Association. The project includes an expansion of the Williston Regional Water Treatment Plant from a 2013 capacity of 37,850 cubic meters per day (CMD) to 79,500 CMD by 2015 . In addition, new transmission lines, storage reservoirs, pump stations, and depots for trucks delivering water to drilling operations will be constructed.

The WAWS project was authorized by the North Dakota State Legislature in 2011 and is supported by the State of North Dakota with grants, loans, and a loan guarantee but will not receive federal funding. The WAWS project includes a transfer of treated water into Divide and Burke counties and, correspondingly, into the Mouse River basin. Without federal funds, the WAWS project can proceed quickly and will not be hampered by legal requirements for an environmental impact statement, and the inevitable challenges by downstate and Canadian opponents.

However, the innovative WAWS funding model includes the use of the pipelines to sell water to oil drilling and production operations. This will allow the system to be built to serve the expanding population. With expected population growth, the system is being built for a capacity larger than the needs of the current residential population. Early projections estimated that the oil industry would fund 80 percent of project costs [20]. This will place them in direct completion with private water sellers. Private water sellers have generally made large investments in supplying the drillers with water for their operations. In the 2012-2013 legislative period, they lobbied hard to restrict the WAWS industrial water sales. A compromise was reached requiring the SWC to approve the siting of all new industrial water depots [21]. The law also prescribed the use of industrial water sales revenue toward loan repayment [22]. A compilation of SWC data on Fresh Water Depots shows that nine of 502 water depots are WAWS depots.

Although these water systems have had favorable support from the state, and, for the NAWS and SWPP projects by the federal government, a number of challenges face these systems. All of these projects transport Missouri River water over great distances. This is due to low population density and the limited access that these systems have to the Missouri River. In addition, often old water pipelines, installed before the current population expansion, are being used. These older pipes may not be suited to the increased pressure and volumes required with population growth.

Another challenge that faces the expansion, of both the WAWS and SWPP systems, is the difficulties in gaining access to right of ways through private land for water pipes. Although water projects can use the right of eminent domain to condemn land for pipelines, they try to avoid this and will even reroute pipelines in order to minimize conflict with landowners. Private sector pipelines, for oil, water, and fracking wastewater, do pay for easements to compensate property owners for pipeline access and inconvenience. The WAWS project pays for right of way for its main transmission pipes, but not for smaller distribution pipes. Study participants cited "landowner fatigue" as a source of difficulties. Often contractors who install pipelines are not from the region, and only quickly cover pipeline ditches without attention to soil reclamation. Study participants cited efforts by the WAWS in maintaining its own reclamation team as a means of ensuring good relations with landowners.

A third difficulty is the high costs and resource shortages that have accompanied the oil boom. Roads have been congested. The shortage of skilled and unskilled labor has increased wages. Prices for 
equipment and parts have also escalated. The contractors that have the capacity to install pipelines and water systems have been very busy with other urgent infrastructure development projects. Winters also restrict the construction season.

\section{Conclusions}

Assessing the benefits of reallocating water across uses requires an assessment of physical and legal feasibility as well and economic net benefits. As noted, the minimal flows in the Missouri River at Williston, ND since 1898 have been 11.1 cubic kilometers per year. Permitted use of water in North Dakota is minimal. Thus, water is both physically and legally available in western North Dakota for use in oil drilling, livestock, and household needs.

The USACE operates the Pick-Sloan dams and reservoirs to simultaneously achieve many purposes. The traditional priorities of the Pick-Sloan dam system have always been flood control and navigation. Recent initiatives to maintain ecosystem services have pushed the USACE to modify its dam operations. However, after years of litigation and slightly revised dam operation rules, the USACE continues to manage upper Missouri River Dams with a priority to maintain the $1181 \mathrm{~km}$ long, $91 \mathrm{~m}$ wide, and $2.7 \mathrm{~m}$ deep channel from Sioux City, Iowa to the confluence with the Mississippi River from later March until early December. This challenge is expected to be encumbered by the impacts of increased droughts that are expected to accompany global climate change [23]. The navigation that this channel facilitates is generally located in the state of Missouri where sand and gravel is transported over small distances. The opportunity cost of the relatively small volumes of water used in western North Dakota to support this downstream navigation is negligible [24]. Certainly, Missouri River water also supports navigation on the lower Mississippi. However, water from the more humid upper Mississippi and Ohio basins is much more important in this channel.

North Dakota has a considerable financial incentive to facilitate the oil boom and the expansion of the western North Dakota economy. The expansion of water supply systems for industrial, ranch, and household uses is necessary to support oil development and to ensure the sustainable growth in the region's economy. The USACE's restrictions on use of Lake Sakakawea water for industrial uses imply increased costs to water system expansion, as water transmission pipes will need to cover long distances across the north and south sides of the lake. This should impose substantial increased capital costs on the construction of the system. It may also increase operating costs because of increased potential for breaks and leaks.

Fortunately for North Dakota, the state was prescient when it established the Resources Trust fund to support water related projects with oil extraction tax revenue in 1990. The funding available for water projects allows the regional water systems to expand services and to meet the growing demand for potable water. The expansion of these water systems allows the oil industry, and accompanying service industries, to grow. In addition, it brings improved quality of life to town and farm households. Unfortunately, low prices have also reduced revenue into North Dakota Resources trust funds.

A further opportunity has developed with the revenue provided by sales of water to the oil industry. This has supported the capital costs of the expansion of the WAWS system. This is acceptable to the oil industry because it provides relatively secure alternative supply depots of relatively clean water, at the market price. It is in competition with private water sellers, but these water sellers have always been constrained by the lack of secure permanent water rights to the water that they have been selling. Fortunately, for the oil industry, the initial years of the oil boom have coincided with a period of good precipitation, and temporary water permits have been available. When drier years come, which should be expected before drilling ceases, alternative sources of industrial water will be fewer, and the public water systems will become more important to the industry. Thus, the continued use of the public water systems as sources of industrial water should be facilitated. Furthermore, the prohibition on selling water rights previously dedicated to irrigation to industrial uses should be addressed by the legislature and eliminated in order to allow water to flow to its more valuable uses. 
North Dakota has alternatively tried to seek federal funding for certain water projects and to avoid federal entanglements in others. Currently, North Dakota has acted to avoid certain projects that involve discretionary federal government decisions, including funding that may trigger an Environmental Impact Assessment, because of the delays that occur and the fear of court challenges. For example, a recent review of alternatives to bring Missouri River water to Jamestown, inside the Missouri River basin, has identified routes that would minimize the "schedule risk" from federal government compliance efforts [25]. North Dakota needs to bring secure water supplies to remote areas of the Mouse River basin and North Dakota is experienced with the delays imposed upon the NAWS project. In addition, efforts should be made to minimize any risk of invasive species transfer. The recommendations presented in the 2015 NAWS Environmental Impact Statement to treat water prior to an interbasin transfer should be considered to be a benchmark for further water transfers.

The state should continue to support infrastructure development in the region, since drilling and oil production could be expected to continue through the next thirty to fifty years. The slowdown in drilling caused by low oil prices should be considered to be advantageous to the development of public infrastructure, like the regional water projects. The slowdown should make it easier to hire contractors and to purchase needed equipment. State funding for most of these development projects comes directly from oil production taxes, and thus should continue although with lower revenue.

There are a number of scenarios that could imply that water is a constraining factor in the sustainable growth of both North Dakota's oil and gas industry and western North Dakota's residential communities. The SWC and the regional water supply projects have made considerable advances to reduce the possibility of this constraint. This has been facilitated by the water purchased by the oil industry. Although rural communities and households have relied upon groundwater for decades, the growing rural systems have increased opportunities to improve the quality of their water and their standard of living. The WAWS project is currently being constructed to exceed current residential capacity. Water that is surplus to residential needs is being sold to drilling operations. This excess capacity should eventually make it feasible to diversify the regional economy with water intensive businesses such as food processing and bottling plants.

Western North Dakota remains an anomoly in terms of western US water management. The region is semi-arid, with a rapid increase in population, and a relatively thirsty oil drilling and production industry. The normal scarcity that would more generally lead to reallocation of water, perhaps through water markets, does not exist due to the large quantity of water that flows through the Missouri River and is stored in Lake Sakakawea. Among the legacies of the federal government's management of the Missouri River in North Dakota has been the large storage of water in Lake Sakakawea without a large accompanying surface irrigation system. A number of federally supported systems in the western USA, such as the Central Arizona Project, have inefficiently used scarce water and funding [26,27]. The oil boom will imply that efforts to use Missouri River water in western North Dakota will be highly beneficial.

Acknowledgments: Research was supported, in part, by a grant from the North Central Regional Center for Rural Development at Michigan State University and, in part, by the National Institute of Food and Agriculture, U.S. Department of Agriculture, under Project No. ND01315.

Author Contributions: Robert R. Hearne and Felix Fernando conceived of this research, conducted the review and wrote the paper.

Conflicts of Interest: The authors declare no conflict of interest.

\section{References}

1. North Dakota State Water Commission. North Dakota 2015 State Water Management Plan. Available online: http:/ / www.swc.nd.gov/4dlink9/4dcgi/GetSubCategoryRecord/Reports\%20and\%20Publications / Water\%20Management\%20Plans (accessed on 15 June 2015).

2. Barbour, R.S. Checklists for improving rigor in qualitative research: A case of the tail wagging the dog? Br. Med. J. 2001, 322, 1115-1117. [CrossRef] 
3. Current Results Weather and Science Facts "North Dakota Weather Averages". Available online: http://www.currentresults.com/Weather/North-Dakota/average-north-dakota-weather.php (accessed on 12 March 2015).

4. United States Department of Agriculture (USDA). Census of Agriculture. Available online: http://www. agcensus.usda.gov / (accessed on 15 June 2016).

5. Center for Social Research at NDSU. North Dakota Statewide Housing Assessment Resource Project. Available online: https:/ /www.ndsu.edu/sdc/sharp/population.php (accessed on 2 August 2016).

6. United States Census Bureau. North Dakota. Available online: http://www.census.gov/quickfacts/table/ PST045215/38 (accessed on 2 August 2016).

7. North Dakota Drilling and Production Statistics. Available online: https://www.dmr.nd.gov/oilgas/stats/ statisticsvw.asp (accessed on 15 June 2016).

8. Bangsund, D.; Hodur, N. Williston Basin 2012: Projections of Future Employment and Population. North Dakota Summary. Available online: https:/ /www.ag.ndsu.edu/agecon/research-extension-centers / agribusiness-and-applied-economics-reports (accessed on 15 June 2015).

9. United States Energy Information Agency. North Dakota Crude Oil First Purchase Price. 2015. Available online: http:/ / www.eia.gov/dnav/pet/hist/LeafHandler.ashx?n=pet\&s=f002038_3\&f=m (accessed on 15 June 2016).

10. Helms, L.D. North Dakota Department of Mineral Resources. In Presented at the House Appropriations Committee, Bismarck, ND, USA, 1 August 2015.

11. Hearne, R.; Shakya, S.; Yin, Q. The value of fracking wastewater treatment and recycling technologies in North Dakota. J. Water Reuse Desalin. 2015, 5, 211-222. [CrossRef]

12. Lauer, N.; Harkness, J.; Vengosh, A. Brine Spills Associated with Unconventional Oil Development in North Dakota. Environ. Sci. Technol. 2016, 50, 5389-5397. [CrossRef] [PubMed]

13. Schuh, W.M. Water Appropriation Requirements, Current Water Use, \& Water Availability for Energy Industries in North Dakota: A 2010 Summary. Available online: http://www.swc.nd.gov/info_edu/ reports_and_publications/pdfs/wr_investigations/wr49_report.pdf (accessed on 21 July 2016).

14. Guhin, J. The Law of the Missouri River. S. D. Law Rev. 1985, 30, 350-488.

15. Seeronen, J. Judicial Challenges to Missouri River Mainstem Regulation. MO. Environ. Law Policy Rev. 2009, 16, 59-107.

16. Brandson, N.; Hearne, R. Devils Lake and Red River Basin. In Water without Borders? Canada, the U.S., and Transboundary Waters; Norman, E.S., Ed.; University of Toronto Press: Toronto, ON, Canada, 2013; pp. 179-192.

17. Letter to Colonel Robert Ruch, United States Army Corps of Engineers, Omaha District. Available online: http://www.swc.state.nd.us/pdfs/state_engineer_corps-comments_lake_sakakawea_a.pdf (accessed on 2 August 2016).

18. U.S. Army Corps of Engineers Omaha District. Garrison Dam/Lake Sakakawea Surplus Water Report. Available online: https://denr.sd.gov/mr/PublicDraftSakakaweaSurplusWaterReport.pdf (accessed on 20 November 2015).

19. Hearne, R.; Prato, T. Institutional Evolution of Missouri River Management. Water Policy 2016, 18, 619-634. [CrossRef]

20. Ormer, V.A. Energy: Water Project Expected to Assist Western North Dakota; Prairie Business: Grand Forks, ND, USA, 2011; pp. 32-34.

21. Smith, N. Water Project Compromise 'Manageable'. Available online: http://bismarcktribune.com/bakken/ water-project-compromise-manageable/article_c809d160-bf30-11e2-b944-001a4bcf887a.html (accessed on 15 June 2015).

22. Sixty-Third Legislative Assembly of North Dakota, SENATE BILL NO. 2233. Available online: http:/ / www. legis.nd.gov/assembly/63-2013/documents/13-0579-04000.pdf?20150624130233 (accessed on 15 June 2015).

23. Shafer, M.; Ojima, D.; Antle, J.M.; Kluck, D.; McPherson, R.A.; Petersen, S.; Scanlon, B.; Sherman, K. Chapter 19: Great Plains. In Climate Change Impacts in the United States: The Third National Climate Assessment; U.S. Global Change Research Program: Washington, DC, USA, 2014; pp. 441-461. 
24. United States Government Accountability Office. Missouri River Navigation: Data on Commodity Shipments for Four States Served by the Missouri River and Two States Served by Both the Missouri and Mississippi Rivers, Report GAO-09-224R. Available online: http:/ /www.gao.gov/products/GAO-09-224R (accessed on 12 November 2014).

25. Spiller, B.; Jochim, B.; Case, S. Central North Dakota Water Supply Project Alternative Study: Final Report. 2015. Available online: http://www.swc.nd.gov/4dlink9/4dcgi/GetContentPDF/PB-3546/ CentralNDWaterSupply_FinalReport_15-0408.pdf (accessed on 15 June 2015).

26. Wilson, P. Economic discovery in federally supported irrigation districts: A tribute to William E. Martin and friends. J. Agric. Resour. Econ. 1997, 22, 61-77.

27. Maass, A.; Anderson, R.L. ... and the Desert Shall Rejoice: Conflict, Growth and Justice in Arid Environments; MIT Press: Cambridge, MA, USA, 1978.

(C) 2016 by the authors; licensee MDPI, Basel, Switzerland. This article is an open access article distributed under the terms and conditions of the Creative Commons Attribution (CC-BY) license (http://creativecommons.org/licenses/by/4.0/). 